\title{
SISTEM PEMBIAYAAN KESEHATAN
}

\author{
Febri Endra Budi Setyawan
}

\author{
Fakultas Kedokteran, Universitas Muhammadiyah Malang, J1. Bendungan Sutami 188 A Sumbersari malang, \\ Lowokwaru, Kota Malang, 65145, Indonesia, (0341) 582060
}

\begin{abstract}
ABSTRAK
Pembangunan kesehatan adalah bagian dari pembangunan nasional, dalam pembangunan kesehatan tujuan yang ingin dicapai adalah meningkatkan derajat kesehatan masyarakat yang optimal. Kenyataan yang terjadi sampai saat ini derajat kesehatan masyarakat masih rendah khususnya pada masyarakat miskin. Hal ini dapat digambarkan bahwa derajat kesehatan masyarakat miskin berdasarkan indikator Angka Kematian Bayi (AKB) dan Angka Kematian Ibu (AKI) di Indonesia, masih cukup tinggi, yaitu AKB sebesar 35 per 1000 kelahiran hidup dan AKI sebesar 307 per 100.000 kelahiran hidup. Salah satu penyebabnya adalah karena mahalnya biaya kesehatan sehingga akses ke pelayanan kesehatan pada umumnya masih rendah. Asuransi kesehatan adalah salah satu upaya untuk mengatasi masalah ketidakmampuan terhadap pembiayaan pelayanan kesehatan.
\end{abstract}

\section{PENDAHULUAN}

Pelayanan kesehatan masyarakat pada prinsipnya mengutamakan pelayanan kesehatan promotif dan preventif. Pelayanan promotif adalah upaya meningkatkan kesehatan masyarakat ke arah yang lebih baik lagi dan yang preventif mencegah agar masyarakat tidak jatuh sakit agar terhindar dari penyakit. Sebab itu pelayanan kesehatan masyarakat itu tidak hanya tertuju pada pengobatan individu yang sedang sakit saja, tetapi yang lebih penting adalah upaya-upaya pencegahan (preventif) dan peningkatan kesehatan (promotif). Sehingga, bentuk pelayanan kesehatan bukan hanya puskesmas atau balkesmas saja, tetapi juga bentukbentuk kegiatan lain, baik yang langsung kepada peningkatan kesehatan dan pencegahan penyakit, maupun yang secara tidak langsung berpengaruh kepada peningkatan kesehatan. (Juanita, 2002).

Pelayanan kesehatan dibedakan dalam dua golongan, yaitu :

1. Pelayanan kesehatan primer (primary health care), atau pelayanan kesehatan masyarakat adalah pelayanan kesehatan yang paling depan, yang pertama kali diperlukan masyarakat pada saat mereka mengalami ganggunan kesehatan atau kecelakaan.

2. Pelayanan kesehatan sekunder dan tersier (secondary and tertiary bealth care), adalah rumah sakit, tempat masyarakat memerlukan perawatan lebih lanjut atau rujukan. Di Indonesia terdapat berbagai tingkat rumah sakit, mulai dari rumah sakit tipe D sampai dengan Rumah sakit kelas A. (Juanita, 2002).

Untuk memenuhi kebutuhan dan tuntutan masyarakat terhadap kesehatan banyak hal yang harus dilakukan, salah satunya adalah penyelenggaraan pelayanan kesehatan. Secara umum dapat dibedakan 9 (sembilan) syarat penyelenggaraan pelayanan kesehatan yang baik, yakni tersedia (available), menyeluruh (comprehensive), berkesinambungan (countinues), terpadu (integrated), wajar (appropiate), dapat diterima (acceptable), bermutu (quality), tercapai (accessible) serta terjangkau (affordable). (Azwar Azrul ,1999).

Dampak krisis ekonomi di Indonesia sampai saat ini meluas ke seluruh bidang kehidupan, termasuk bidang pelayanan kesehatan. Dilema yang dihadapi pelayanan kesehatan, disatu pihak pelayanan kesehatan harus menjalankan misi sosial, yakni merawat dan menolong yang sedang menderita tanpa memandang sosial, ekonomi, agama dan sebagainya. Namun dipihak lain pelayanan kesehatan harus bertahan secara ekonomi dalam menghadapi badai krisis tersebut. Oleh sebab itu pelayanan kesehatan harus melakukan reformasi, reorientasi dan revitalisasi. (Juanita, 2002).

Reformasi kebijakan pembangunan kesehatan telah selesai dilakukan sebagaimana telah tertuang dalam Visi, Misi, Strategi dan Paradigma baru pembangunan kesehatan yang populer dengan sebutan Indonesia Sehat. Reformasi Sistem Kesehatan Nasional (SKN) telah memberi arah baru pembangunan kesehatan di Indonesia. Jika diperhatikan kebijakan dan sistem baru hasil reformasi tersebut tampak banyak perubahan yang akan dilakukan, dua diantaranya yang terpenting adalah perubahan pada subsistem upaya kesehatan dan perubahan pada subsistem pembiayaan kesehatan. (Gotama I, Pardede D, 2010).

Penggalian, pengalokasian dan pembelanjaan sumber daya keuangan dalam subsistem pembiayaan kesehatan dilakukan untuk membiayai UKM dan UKP penduduk miskin dengan mobilisasi dan dari masyarakat, pemerintah dan public-private mix. Sedangkan untuk penduduk mampu, pembiayaan kesehatan masyarakat terutama dari masyarakat itu sendiri dengan mekanisme jaminan kesehatan baik wajib maupun sukarela. (Gotama I, Pardede D, 2010).

\section{PEMBIAYAAN KESEHATAN}

Proses pelayanan kesehatan tidak bisa dipisahkan dengan pembiayaan kesehatan. Biaya kesehatan ialah besarnya dana yang harus disediakan untuk menyelenggarakan dan atau memanfaatkan berbagai upaya kesehatan yang diperlukan oleh perorangan, keluarga, kelompok dan masyarakat. 
Berdasarkan pengertian ini, maka biaya kesehatan dapat ditinjau dari dua sudut yaitu berdasarkan:

1. Penyedia Pelayanan Kesehatan (Health Provider), adalah besarnya dana yang harus disediakan untuk dapat menyelenggarakan upaya kesehatan, maka dilihat pengertian ini bahwa biaya kesehatan dari sudut penyedia pelayanan adalah persoalan utama pemerintah dan ataupun pihak swasta, yakni pihak-pihak yang akan menyelenggarakan upaya kesehatan. Besarnya dana bagi penyedia pelayanan kesehatan lebih menunjuk kepada seluruh biaya investasi (investment cost) serta seluruh biaya operasional (operational cost).

2. Pemakai Jasa Pelayanan (Health consumer), adalah besarnya dana yang harus disediakan untuk dapat memanfaatkan jasa pelayanan. Dalam hal ini biaya kesehatan menjadi persoalan utama para pemakai jasa pelayanan, namun dalam batas-batas tertentu pemerintah juga turut serta, yakni dalam rangka terjaminnya pemenuhan kebutuhan pelayanan kesehatan bagi masyarakat yang membutuhkannya. Besarnya dana bagi pemakai jasa pelayanan lebih menunjuk pada jumlah uang yang harus dikeluarkan (out of pocket) untuk dapat memanfaatkan suatu upaya kesehatan. (Azwar, A. 1999).

Pembiayaan kesehatan yang kuat, stabil dan berkesinambungan memegang peranan yang amat vital untuk penyelenggaraan pelayanan kesehatan dalam rangka mencapai berbagai tujuan penting dari pembangunan kesehatan di suatu negara diantaranya adalah pemerataan pelayanan kesehatan dan akses (equitable access to bealth care) dan pelayanan yang berkualitas (assured quality). Oleh karena itu reformasi kebijakan kesehatan di suatu negara seyogyanya memberikan fokus penting kepada kebijakan pembiayaan kesehatan untuk menjamin terselenggaranya kecukupan (adequacy), pemerataan (equity), efisiensi (efficiency) dan efektifitas (effectiveness) dari pembiayaan kesehatan itu sendiri. (Departemen Kesehatan RI, 2004).

Perencanaan dan pengaturan pembiayaan kesehatan yang memadai (health care financing) akan menolong pemerintah di suatu negara untuk dapat memobilisasi sumber-sumber pembiayaan kesehatan, mengalokasikannya secara rasional serta menggunakannya secara efisien dan efektif. Kebijakan pembiayaan kesehatan yang mengutamakan pemerataan serta berpihak kepada masyarakat miskin (equitable and pro poor health policy) akan mendorong tercapainya akses yang universal. Pada aspek yang lebih luas diyakini bahwa pembiayaan kesehatan mempunyai kontribusi pada perkembangan sosial dan ekonomi. Pelayanan kesehatan itu sendiri pada akhir-akhir ini menjadi amat mahal baik pada negara maju maupun pada negara berkembang. Penggunaan yang berlebihan dari pelayanan kesehatan dengan teknologi tinggi adalah salah satu penyebab utamanya. Penyebab yang lain adalah dominasi pembiayaan pelayanan kesehatan dengan mekanisme pembayaran tunai (fee for service) dan lemahnya kemampuan dalam penatalaksanaan sumber-sumber dan pelayanan itu sendiri (poor management of resources and services). (Departemen Kesehatan RI, 2004).

Pelayanan kesehatan memiliki beberapa ciri yang tidak memungkinkan setiap individu untuk menanggung pembiayaan pelayanan kesehatan pada saat diperlukan:
1) Kebutuhan pelayanan kesehatan muncul secara sporadik dan tidak dapat diprediksikan, sehingga tidak mudah untuk memastikan bahwa setiap individu mempunyai cukup uang ketika memerlukan pelayanan kesehatan.

2) Biaya pelayanan kesehatan pada kondisi tertentu juga sangat mahal, misalnya pelayanan di rumah sakit maupun pelayanan kesehatan canggih (operasi dan tindakan khusus lain), kondisi emergensi dan keadaan sakit jangka panjang yang tidak akan mampu ditanggung pembiayaannya oleh masyarakat umum.

3) Orang miskin tidak saja lebih sulit menjangkau pelayanan kesehatan, tetapi juga lebih membutuhkan pelayanan kesehatan karena rentan terjangkit berbagai permasalahan kesehatan karena buruknya kondisi gizi, perumahan.

4) Apabila individu menderita sakit dapat mempengaruhi kemampuan untuk berfungsi termasuk bekerja, sehingga mengurangi kemampuan membiayai. (Departemen Kesehatan RI, 2004).

Berdasarkan karakteristik tersebut, sebuah sistem pembiayaan pelayanan kesehatan haruslah bertujuan untuk:

1) Risk spreading, pembiayaan kesehatan harus mampu meratakan besaran resiko biaya sepanjang waktu sehingga besaran tersebut dapat terjangkau oleh setiap rumah tangga. Artinya sebuah sistem pembiayaan harus mampu memprediksikan resiko kesakitan individu dan besarnya pembiayaan dalam jangka waktu tertentu (misalnya satu tahun). Kemudian besaran tersebut diratakan atau disebarkan dalam tiap bulan sehingga menjadi premi (iuran, tabungan) bulanan yang terjangkau.

2) Risk pooling, beberapa jenis pelayanan kesehatan (meskipun resiko rendah dan tidak merata) dapat sangat mahal misalnya hemodialisis, operasi spesialis (jantung koroner) yang tidak dapat ditanggung oleh tabungan individu (risk spreading). Sistem pembiayaan harus mampu menghitung dengan mengakumulasikan resiko suatu kesakitan dengan biaya yang mahal antar individu dalam suatu komunitas sehingga kelompok masyarakat dengan tingkat kebutuhan rendah (tidak terjangkit sakit, tidak membutuhkan pelayanan kesehatan) dapat mensubsidi kelompok masyarakat yang membutuhkan pelayanan kesehatan. Secara sederhana, suatu sistem pembiayaan akan menghitung resiko terjadinya masalah kesehatan dengan biaya mahal dalam satu komunitas, dan menghitung besaran biaya tersebut kemudian membaginya kepada setiap individu anggota komunitas. Sehingga sesuai dengan prinsip solidaritas, besaran biaya pelayanan kesehatan yang mahal tidak ditanggung dari tabungan individu tapi ditanggung bersama oleh masyarakat.

3) Connection between ill-health and poverty, karena adanya keterkaitan antara kemiskinan dan kesehatan, suatu sistem pembiayaan juga harus mampu memastikan bahwa orang miskin juga mampu pelayanan kesehatan yang layak sesuai standar dan kebutuhan sehingga tidak harus mengeluarkan pembiayaan yang besarnya tidak proporsional dengan pendapatan. Pada umumnya 
di negara miskin dan berkembang hal ini sering terjadi. Orang miskin harus membayar biaya pelayanan kesehatan yang tidak terjangkau oleh penghasilan mereka dan juga memperoleh pelayanan kesehatan di bawah standar.

4) Fundamental importance of health, kesehatan merupakan kebutuhan dasar dimana individu tidak dapat menikmati kehidupan tanpa status kesehatan yang baik

Organisasi kesehatan se-dunia (WHO) sendiri memberi fokus strategi pembiayaan kesehatan yang memuat isu-isu pokok, tantangan, tujuan utama kebijakan dan program aksi itu pada umumnya adalah dalam area sebagai berikut:

1) Meningkatkan investasi dan pembelanjaan publik dalam bidang kesehatan

2) Mengupayakan pencapaian kepesertaan semesta dan penguatan permeliharaan kesehatan masyarakat miskin

3) Pengembangan skema pembiayaan praupaya termasuk didalamnya asuransi kesehatan sosial

4) Penggalian dukungan nasional dan internasional

5) Penguatan kerangka regulasi dan intervensi fungsional

6) Pengembangan kebijakan pembiayaan kesehatan yang didasarkan pada data dan fakta ilmiah

7) Pemantauan dan evaluasi.

Implementasi strategi pembiayaan kesehatan di suatu negara diarahkan kepada beberapa hal pokok yakni; kesinambungan pembiayaan program kesehatan prioritas, reduksi pembiayaan kesehatan secara tunai perorangan (out of pocket funding), menghilangkan hambatan biaya untuk mendapatkan pelayanan kesehatan, pemerataan dalam akses pelayanan, peningkatan efisiensi dan efektifitas alokasi sumber daya (resources) serta kualitas pelayanan yang memadai dan dapat diterima pengguna jasa. Sumber dana biaya kesehatan berbeda pada beberapa negara, namun secara garis besar berasal dari:

1. Anggaran pemerintah.

2. Anggaran masyarakat.

3. Bantuan biaya dari dalam dan luar negeri.

4. Gabungan anggaran pemerintah dan masyarakat.

Tingginya biaya kesehatan disebabkan oleh beberapa hal, beberapa yang terpenting diantaranya sebagai berikut:

1. Tingkat inflasi

Apabila terjadi kenaikan harga di masyarakat, maka secara otomatis biaya investasi dan juga biaya operasional pelayanan kesehatan akan meningkat pula, yang tentu saja akan dibebankan kepada pengguna jasa.

2. Tingkat permintaan

Pada bidang kesehatan, tingkat permintaan dipengaruhi sedikitnya oleh dua faktor, yaitu meningkatnya kuantitas penduduk yang memerlukan pelayanan kesehatan, yang karena jumlahnya lebih atau bertambah banyak, maka biaya yang harus disediakan meningkat pula. Faktor kedua adalah meningkatnya kualitas penduduk. Dengan tingkat pendidikan dan penghasilan yang lebih baik, mereka akan menuntut penyediaan layanan kesehatan yang baik pula dan hal ini membutuhkan biaya pelayanan kesehatan yang lebih baik dan lebih besar.
3. Kemajuan ilmu dan teknologi

Sejalan dengan adanya kemajuan ilmu dan teknologi dalam penyelenggaraan pelayanan kesehatan (penggunaan peralatan kedokteran yang modern dan canggih) memberikan konsekuensi tersendiri, yaitu tingginya biaya yang harus dikeluarkan dalam berinvestasi. Hal ini membawa akibat dibebankannya biaya investasi dan operasional tersebut pada pemakai jasa pelayanan kesehatan.

4. Perubahan Pola Penyakit

Meningkatnya biaya kesehatan juga dipengaruhi adanya perubahan pola penyakit, yang bergeser dari penyakit yang sifatnya akut menjadi penyakit yang bersifat kronis. Dibandingkan dengan berbagai penyakit akut, perawatan berbagai penyakit kronis ternyata lebih lama. Akibatnya biaya yang dikeluarkan untuk perawatan dan penyembuhan penyakit ini akan lebih besar. Hal ini akan sangat mempengaruhi tingginya biaya kesehatan.

5. Perubahan pola pelayanan kesehatan

Perubahan pola pelayanan kesehatan ini terjadi akibat perkembangan keilmuan dalam bidang kedokteran sehingga terbentuk spesialisasi dan subspesialisasi yang menyebabkan pelayanan kesehatan menjadi terkotakkotak (fragmented health service) dan satu sama lain seolah tidak berhubungan. Akibatnya sering terjadi tumpang tindih atau pengulangan metoda pemeriksaan yang sama dan pemberian obat-obatan yang dilakukan pada seorang pasien, yang tentu berdampak pada semakin meningkatnya beban biaya yang harus ditanggung oleh pasien selaku pengguna jasa layanan kesehatan ini. Selain itu, dengan adanya pembagian spesialisasi dan subspesialisasi tenaga pelayanan kesehatan, menyebabkan hari perawatan juga akan meningkat.

6. Perubahan Pola Hubungan Dokter-Pasien

Sistem kekeluargaan yang dulu mendasari hubungan dokter-pasien seakan sirna. Dengan adanya perkembangan spesialisasi dan subspesialisasi serta penggunaan berbagai peralatan yang ditunjang dengan kemajuan ilmu dan teknologi, mengakibatkan meningkatnya biaya yang harus dikeluarkan oleh pasien, hal ini tentu saja membuat pasien menuntut adanya kepastian pengobatan dan penyembuhan dari penyakitnya. Hal ini diperberat dengan semakin tingginya tingkat pendidikan pasien selaku pengguna jasa layanan kesehatan, yang mendorong semakin kritisnya pemikiran dan pengetahuan mereka tentang masalah kesehatan. Hal tersebut diatas mendorong para dokter sering melakukan pemeriksaan yang berlebihan (over utilization), demi kepastian akan tindakan mereka dalam melakukan pengobatan dan perawatan, dan juga dengan tujuan mengurangi kemungkinan kesalahan yang dilakukan dalam mendiagnosa penyakit yang diderita pasiennya. Konsekuensi yang terjadi adalah semakin tingginya biaya yang dibutuhkan oleh pasien untuk mendapatkan pelayanan kesehatan.

7. Lemahnya mekanisme pengendalian biaya

Kurangnya peraturan perundang-undangan yang ditetapkan untuk mengatur dan membatasi pemakaian biaya pelayanan kesehatan menyebabkan pemakaiannya sering tidak terkendali, yang akhirnya akan membebani 
penanggung (perusahaan) dan masyarakat secara keseluruhan.

8. Penyalahgunaan asuransi kesehatan

Asuransi kesehatan (health insurance) sebenamya merupakan salah satu mekanisme pengendalian biaya kesehatan, sesuai dengan anjuran yang diterapkan oleh pemerintah. Tetapi jika diterapkan secara tidak tepat sebagaimana yang lazim ditemukan pada bentuk yang konvensional (third party sistem) dengan sistem mengganti biaya (reimbursement) justru akan mendorong naiknya biaya kesehatan. (Medis Online, 2009).

Biaya kesehatan banyak macamnya, karena kesemuanya tergantung dari jenis dan kompleksitas pelayanan kesehatan yang diselenggarakan dan atau yang dimanfaatkan. Hanya saja disesuaikan dengan pembagian pelayanan kesehatan, maka biaya kesehatan tersebut dapat dibedakan atas dua macam yaitu:

1) Biaya pelayanan kedokteran

Biaya yang dimaksudkan adalah yang dibutuhkan untuk menyelenggarakan dan atau memanfaatkan pelayanan kedokteran, yakni yang tujuan utamanya untuk mengobati penyakit serta memulihkan kesehatan penderita.

2) Biaya pelayanan kesehatan masyarakat

Biaya yang dimaksud adalah yang dibutuhkan untuk menyelenggarakan dan atau memanfaatkan pelayanan kesehatan masyarakat yaitu yang tujuan utamanya untuk memelihara dan meningkatkan kesehatan serta untuk mencegah penyakit.

Sama halnya dengan biaya kesehatan secara keseluruhan, maka masing-masing biaya kesehatan ini dapat pula ditinjau dari dua sudut yaitu dari sudut penyelenggara kesehatan (health provider) dan dari sudut pemakai jasa pelayanan (health consumer).

\section{MODEL SISTEM PEMBIAYAAN}

Pertanyaan yang mengemuka ialah model kebijakan kesehatan seperti apa yang layak diterapkan di Indonesia, sistem pembiayaan yang bagaimana yang cocok dengan kehidupan masyarakat kita. Terdapat beberapa model sistem pembiayaan pelayanan kesehatan yang dijalankan oleh beberapa negara, berdasarkan sumber pembiayaannya:

1. Direct Payments by Patients

Ciri utama model direct payment adalah setiap individu menanggung secara langsung besaran biaya pelayanan kesehatan sesuai dengan tingkat penggunaannya. Pada umumnya sistem ini akan mendorong penggunaan pelayanan kesehatan secara lebih hati-hati, serta adanya kompetisi antara para provider pelayanan kesehatan untuk menarik konsumen atau free market. Meskipun tampaknya sehat, namun transaksi kesehatan pada umumnya bersifat tidak seimbang dimana pasien sebagai konsumen tidak mampu mengenali permasalahan dan kebutuhannya, sehingga tingkat kebutuhan dan penggunaan jasa lebih banyak diarahkan oleh provider. Sehingga free market dalam pelayanan kesehatan tidak selalu berakhir dengan peningkatan mutu dan efisiensi namun dapat mengarah pada penggunaan terapi yang berlebihan.

2. User payments

Dalam model ini, pasien membayar secara langsung biaya pelayanan kesehatan baik pelayanan kesehatan pemerintah maupun swasta. Perbedaannya dengan model informal adalah besaran dan mekanisme pembayaran, juga kelompok yang menjadi pengecualian telah diatur secara formal oleh pemerintah dan provider. Bentuk yang paling kompleks adalah besaran biaya yang bebeda setiap kunjungan sesuai dengan jasa pelayanan kesehatan yang diberikan (biasanya terjadi untuk fasilitas pelayanan kesehatan swasta). Namun model yang umum digunakan adalah 'flat rate', dimana besaran biaya per-episode sakit bersifat tetap.

3. Saving based

Model ini mempunyai karakteristik 'risk spreding' pada individu namun tidak terjadi risk pooling antar individu. Artinya biaya kesehatan langsung, akan ditanggung oleh individu sesuai dengan tingkat penggunaannya, namun individu tersebut mendapatkan bantuan dalam mengelola pengumpulan dana (saving) dan penggunaannya bilamana membutuhkan pelayanan kesehatan. Biasanya model ini hanya mampu mencakup pelayanan kesehatan primer dan akut, bukan pelayanan kesehatan yang bersifat kronis dan kompleks yang biasanya tidak bisa ditanggung oleh setiap individu meskipun dengan mekanisme saving. Sehingga model ini tidak dapat dijadikan model tunggal pada suatu negara, harus didukung model lain yang menanggung biaya kesehatan lain dan pada kelompok yang lebih luas.

\section{Informal}

Ciri utama model ini adalah bahwa pembayaran yang dilakukan oleh individu pada provider kesehatan formal misalnya dokter, bidan tetapi juga pada provider kesehatan lain misalnya: mantri, dan pengobatan tradisional; tidak dilakukan secara formal atau tidak diatur besaran, jenis dan mekanisme pembayarannya. Besaran biaya biasanya timbul dari kesepakatan atau banyak diatur oleh provider dan juga dapat berupa pembayaran dengan barang. Model ini biasanya muncul pada negara berkembang dimana belum mempunyai sistem pelayanan kesehatan dan pembiayaan yang mampu mencakup semua golongan masyarakat dan jenis pelayanan.

5. Insurance Based

Sistem pembiayaan dengan pendekatan asuransi mempunyai perbedaan utama dimana individu tidak menanggung biaya langsung pelayanan kesehatan. Konsep asuransi memiliki dua karakteristik khusus yaitu pengalihan resiko kesakitan pada satu individu pada satu kelompok serta adanya sharing looses secara adil. Secara sederhana dapat digambarkan bahwa satu kelompok individu mempunyai resiko kesakitan yang telah diperhitungkan jenis, frekuensi dan besaran biayanya. Keseluruhan besaran resiko tersebut diperhitungkan dan dibagi antar anggota kelompok sebagai premi yang harus dibayarkan. Apabila anggota kelompok, maka keseluruhan biaya pelayanan kesehatan 
sesuai yang diperhitungkan akan ditanggung dari dana yang telah dikumpulkan bersama. Besaran premi dan jenis pelayanan yang ditanggung serta mekanime pembayaran ditentukan oleh organisasi pengelola dana asuransi.

\section{ASURANSI KESEHATAN}

Dalam kamus atau perbendaharaan kata bangsa Indonesia, tidak dikenal kata asuransi, yang dikenal adalah istilah "jaminan" atau "tanggungan". Dalam konteks asuransi kesehatan, pengertian asuransi adalah memastikan seseorang yang menderita sakit akan mendapatkan pelayanan yang dibutuhkannya tanpa harus mempertimbangkan keadaan ekonominya. Ada pihak yang menjamin atau menanggung biaya pengobatan atau perawatannya. Pihak yang menjamin ini dalam bahasa Inggris disebut insurer atau dalam UU Asuransi disebut asuradur. Asuransi merupakan jawaban atas sifat ketidak-pastian (uncertain) dari kejadian sakit dan kebutuhan pelayanan kesehatan. Untuk memastikan bahwa kebutuhan pelayanan kesehatan dapat dibiayai secara memadai, maka seseorang atau kelompok kecil orang melakukan transfer risiko kepada pihak lain yang disebut insurer/asuradur, ataupun badan penyelenggara jaminan. (Thabrany H, 2001).

Menurut pasal 246 Kitab Undang-Undang Hukum Dagang (KUHD), asuransi mempunyai pengertian sebagai berikut: Asuransi atau pertanggungan adalah suatu persetujuan dimana penanggung kerugian diri kepada tertanggung, dengan mendapat premi untuk mengganti kerugian karena kehilangan kerugian atau tidak diperolehnya suatu keuntungan yang diharapkan, yang dapat diderita karena peristiwa yang tidak diketahui lebih dahulu. (Andreas, 2009). Definisi asuransi menurut Undang-Undang Republik Indonesia Nomor 2 Tahun 1992 adalah Asuransi atau Pertanggungan adalah perjanjian antara dua pihak atau lebih, dimana pihak penanggung mengikatkan diri kepada tertanggung dengan menerima premi asuransi, untuk memberikan penggantian kepada tertanggung karena kerugian, kerusakan atau kehilangan keuntungan yang diharapkan, atau tanggungjawab hukum kepada pihak ketiga yang mungkin akan diderita tertanggung, yang timbul dari suatu peristiwa yang tidak pasti atau untuk memberikan suatu pembayaran yang didasarkan atas meninggal atau hidupnya seseorang yang dipertanggungkan. (Andreas, 2009).

Dalam dunia asuransi ada 6 (enam) macam prinsip dasar yang harus dipenuhi, yaitu:

1) Insurable interest

Hak untuk mengasuransikan, yang timbul dari suatu hubungan keuangan, antara tertanggung dengan yang diasuransikan dan diakui secara hukum.

2) Utmost good faith

Suatu tindakan untuk mengungkapkan secara akurat dan lengkap, semua fakta yang material (material fact) mengenai sesuatu yang akan diasuransikan baik diminta maupun tidak. Artinya adalah: penanggung harus dengan jujur menerangkan dengan jelas segala sesuatu tentang luasnya syarat atau kondisi dari asuransi dan tertanggung juga harus memberikan keterangan yang jelas dan benar atas obyek atau kepentingan yang dipertanggungkan.

\section{3) Proximate cause}

Suatu penyebab aktif, efisien yang menimbulkan rantaian kejadian yang menimbulkan suatu akibat tanpa adanya intervensi suatu yang mulai dan secara aktif dari sumber yang baru dan independen.

4) Indemnity

Suatu mekanisme dimana penanggung menyediakan kompensasi finansial dalam upayanya menempatkan tertanggung dalam posisi keuangan yang ia miliki sesaat sebelum terjadinya kerugian (KUHD pasal 252, 253 dan dipertegas dalam pasal 278).

5) Subrogation

Pengalihan hak tuntut dari tertanggung kepada penanggung setelah klaim dibayar.

6) Contribution

Adalah hak penanggung untuk mengajak penanggung lainnya yang sama-sama menanggung, tetapi tidak harus sama kewajibannya terhadap tertanggung untuk ikut memberikan indemnity.

Pada umumnya model asuransi mendorong munculnya apa yang disebut sebagai moral hazard:

a. Pada sisi tertanggung (pasien): adanya kecenderungan untuk memaksimalkan pelayanan kesehatan karena semua biaya akan ditanggung asuransi, dan kecenderungan untuk tidak melakukan tindakan preventif

b. Pada sisi provider: mempunyai kecenderungan untuk memberikan terapi secara berlebihan untuk memaksimalkan pendapatan.

Sehingga beberapa skema asuransi diatur sedemikian rupa untuk mengurangi terjadinya moral hazard, misalnya dengan mengatur batasan paket pelayanan, mengatur besaran kontribusi sesuai dengan tingkat resiko tertanggung. Sistem ini dapat dibedakan menjadi asuransi yang bersifat umum yaitu mencakup semua golongan dan asuransi yang bersifat khusus untuk kelompok masyarakat tertentu. Sifat asuransi dapat dijelaskan sebagai berikut:

\section{Asuransi bersifat umum}

\section{General taxation}

General taxation merupakan model dimana sumber pembiayaan diambil dari pajak pendapatan secara proporsional dari seluruh populasi yang kemudian dialokasikan untuk berbagai sektor (tidak terbatas pelayanan kesehatan). Alokasi pada sektor kesehatan biasanya berupa budget pada fasilitas kesehatan dan gaji staf kesehatan. Meskipun mempunyai cakupan yang luas, keberhasilan sistem ini tergantung pada tingkat pendapatan masyarakat dan angkatan kerja, besaran alokasi pada pelayanan kesehatan dan sistem penarikan pajak. Rendahnya pendapatan masyarakat (ekonomi negara) akan menurunkan nilai pajak, alokasi biaya pada pelayanan kesehatan sehingga mendorong rendahnya cakupan dan mutu pelayanan sehingga pada akhirnya biaya pelayanan kesehatan akan kembali ditanggung langsung oleh individu.

Earmarked payroll tax

Sistem ini memiliki karakteristik yang hampir serupa dengan general taxation hanya saja penarikan pajak dialokasikan 
langsung bagi pelayanan kesehatan sehingga lebih bersifat transparan dan dapat mendorong kesadaran pembayaran pajak karena kejelasan penggunaan.

\section{Asuransi bersifat khusus}

Dibandingkan dengan sistem umum, asuransi selektif mempunyai perbedaan dalam hal kontribusi dan tanggungan hanya ditujukan pada suatu kelompok tertentu dengan paket pelayanan yang telah ditetapkan.

1. Social insurance

Social insurance mempunyai karakteristik khusus yang membedakan dengan private insurance, yaitu:

a. Keanggotaan bersifat wajib

b. Kontribusi (premi) sesuai dengan besaran gaji

c. Cakupan pelayanan kesehatan yang diasuransikan sesuai dengan besaran kontribusi

d. Pelayanan dirupakan dalam bentuk paket

e. Dikelola oleh organisasi yang bersifat otonom

f. Biasanya merupakan bagian dari sistem jaminan sosial yang berskala luas

g. Umumnya terjadi cross subsidi

2. Voluntary community

Perbedaan utama sistem ini dengan asuransi sosial adalah keanggotaan yang bersifat sukarela serta skala cakupan tertanggung yang lebih sempit. Biasanya asuransi ini berkembang pada kelompok masyarakat yang tidak tertanggung oleh asuransi sosial yaitu kelompok yang tidak memiliki pekerjaan formal, yang tidak memungkinkan untuk dilakukan penarikan kontribusi rutin dari penghasilan. Contoh penerapan dari sistem ini adalah kartu sehat/kartu gakin yang dikembangkan pemerintah daerah dan ditujukan pada kelompok tertentu (masyarakat miskin).

\section{Private Insurance}

Perbedaan utama private insurance dan social insurance adalah tidak adanya risk pooling dan bersifat voluntary. Disamping itu private insurance juga memperhitungkan resiko kesakitan individu dengan besaran premium dan cakupan pelayanan asuransi yang diberikan. Artinya individu yang lebih beresiko sakit misalnya kelompok rentan (bayi, ibu hami, lansia), orang dengan perilaku tertentu misalnya perokok, dan orang dengan pekerjaan yang beresiko akan dikenakan premi yang lebih tinggi dibandingkan kelompok yang dengan resiko rendah. Model ini tentunya mempunyai mekanisme lebih rumit mengingat harus memperhitungkan tingkat resiko tertanggung.

Model private insurance mungkin bersifat profit yaitu mencari keuntungan untuk pengelolaan dan pemilik, atau menggunakan keuntungan untuk mengurangi besaran premi tertanggung. Bentuk private insurance dapat berupa lembaga asuransi swasta atau NGO bagi umum maupun asuransi kelompok khusus seperti asuransi pekerja

\section{Funding/Donation}

Seluruh sistem pembiayaan yang telah diuraikan diatas menganut keterkaitan antara pengguna jasa pelayanan kesehatan atau tertanggung dan penggunaan jasa pelayanan kesehatan. Model funding tidak ditujukan langsung pada kelompok individu tetapi lebih pada program kesehatan misalnya bantuan alat kesehatan, pelatihan atau perbaikan fasilitas pelayanan kesehatan. Permasalahan yang sering muncul adalah ketidaksesuaian program funding dengan kebutuhan atau kesalahan pengelolaan oleh negara. Disamping itu sumber dana dari funding tentu saja tidak dapat diandalkan keberlangsungannya. Berdasarkan pengelolaan manajemennya, sistem pembiayaan menggambarkan hubungan antara pasien sebagai konsumen dan atau sumber biaya, provider/penyelenggara atau pemberi pelayanan kesehatan (dokter, perawat atau institusi seperti rumah sakit), pemerintah sebagai pengatur, pengelola pelayanan kesehatan dan sumber biaya.

Asuransi kesehatan yang paling mutakhir adalah managed care, dimana sistem pembiayaan dikelola secara terintegrasi dengan sistem pelayanan. Asuransi kesehatan dengan model managed care ini mulai dikembangkan di Amerika. Hal ini timbul oleh karena sistem pembiayaan kesehatan yang lama, inflasi biaya kesehatan terus meningkat jauh diatas inflasi rata-rata, sehingga digali model lain untuk mengatasi peningkatan biaya kesehatan. Managed care pada dasarnya sudah mulai diterapkan pada tahun 1983 yaitu oleh kaisar Permanente Medical Care Program, tetapi secara meluas mulai diterapkan pada tahun 1973, yaitu dengan diberlakukannya HMO Act, pada periode pemerintahan Noxon. Juanita, 2002).

Pada hakekatnya, managed care adalah suatu konsep yang masih terus berkembang, sehingga belum ada suatu definisi yang satu dan universal tentang managed care. Namun demikian secara umum dapat didefinisikan bahwa managed care adalah suatu sistem dimana pelayanan kesehatan terlaksana secara terintegrasi dengan sistem pembiayaan kesehatan, yang mempunyai 5 (lima) elemen sebagai berikut:

1. Penyelenggaraan pelayanan kesehatan oleh provider tertentu (selecte provider).

2. Adanya kriteria khusus untuk penetapan provider.

3. Mempunyai program pengawasan mutu dan managemen utilisasi.

4. Penekanan pada upaya promotive dan preventive.

5. Ada financial insentive bagi peserta yang melaksanakan pelayanan sesuai prosedur. (Juanita, 2002).

Organisasi Kesehatan Dunia (WHO) menyatakan alokasi anggaran untuk kesehatan yang ideal adalah sekurangkurangnya $6 \%$ dari anggaran belanja negara (APBN). Sementara itu di negara-negara maju, alokasi anggaran untuk kesehatan mencapai 6\%-15\%. Di Indonesia anggaran untuk Departemen Kesehatan kurang 5\% dari APBN.

Melihat karakteristik tersebut diatas, maka biaya yang timbul akibat gangguan kesehatan (penyakit) merupakan obyek yang layak diasuransikan untuk meringankan beban yang ditanggung oleh penderita serta meningkatkan akses pelayanan kesehatan yang merupakan kebutuhan hidup masyarakat. WHO didalam The World Health Report 2000Health System: Inproving Pervormance juga merekomendasikan untuk mengembangkan sistem pembayaran secara "pre payment', baik dalam bentuk asuransi, tax, maupun social security. Sistem kesehatan haruslah dirancang sedemikian rupa, sehingga bersifat terintegrasi antara sistem pelayanan dan sistem pembiayaan, mutu terjamin (quality assurance) dengan biaya terkendali (cost containment).

Indonesia dengan kondisi yang sangat turbulensi dalam berbagai hal pada saat ini, serta dengan keterbatasan resources 
yang ada, maka sistem managed care merupakan pilihan yang tepat dalam mengatasi masalah pembiayaan kesehatan. Managed care dianggap tepat untuk kondisi di Indonesia, kemungkinan karena sistem pembiayaan managed care dikelola secara terintegrasi dengan sistem pembiayaan, dengan managed care berarti badan pengelola dana (perusahaan asuransi) tidak hanya berperan sebagai juru bayar, sebagaimana berlaku pada asuransi tradisional, tapi ikut berperan dalam dua hal penting, yaitu pengawasan mutu pelayanan (quality contro) dan pengendalian biaya (cost containment). Salah satu elemen managed care adalah bahwa pelayanan diberikan oleh provider tertentu, yaitu yang memenuhi kriteria yang ditetapkan meliputi aspek administrasi, fasilitas sarana, prasarana, prosedur dan proses kerja atau dengan istilah lain meliputi proses bisnis, proses produksi, sarana, produk dan pelayanan. Dengan cara ini, maka pengelola dana (asuransi) ikut mengendalikan mutu pelayanan yang diberikan kepada pesertanya.

\section{PENUTUP}

Peningkatan biaya pelayanan kesehatan yang makin tidak terkendali serta mengantisipasi ketidakmampuan masyarakat dalam mengakses pelayanan kesehatan sehingga perkembangan penyakit semakin tidak terkendali, maka pilihan yang tepat untuk pembiayaan kesehatan adalah asuransi kesehatan. Mengingat kondisi ekonomi negara dan masyarakat serta keterbatasan sumber daya yang ada, maka perlu dikembangkan pilihan asuransi kesehatan dengan suatu pendekatan yang efisien, efektif dan berkualitas agar dapat menjangkau masyarakat luas.

Untuk itu, sudah saatnya dikembangkan asuransi kesehatan nasional dengan managed care sebagai bentuk operasionalnya. Dengan cakupan asuransi yang semakin luas, maka diperlukan jaringan pelayanan (Rumah Sakit) yang semakin luas pula. Tuntutan terhadap pelayanan yang berkualitas baik terhadap penyelenggaraan asuransi kesehatan maupun penyelenggaraan pelayanan kesehatan akan semakin meningkat, upaya peningkatan yang berkesinambungan tidak hanya menjadi tanggungjawab pemberi pelayanan kesehatan saja tetapi juga bagi penyelenggaraan asuransi. Sebaiknya mengikuti program asuransi kesehatan sejak umur yang masih dini. Hal ini untuk mengantisipasi terhadap penolakan keikutsertaan asuransi kesehatan. Oleh karena risiko yang harus ditanggung pada usia tua besar sekali, berbeda dengan kalau masih berusia muda.

\section{DAFTAR PUSTAKA}

..........., 2004, Undang-Undang No. 40 tahun 2004 tentang Sistem Jaminan Sosial Nasional, Sekertaris Negara Republik Indonesia, Jakarta.

Askes PT, 2009, Asuransi Kesehatan Indonesia, Jakarta, Indonesia, Diakses tanggal 10 Desember 2011, (http:/ / I d. W i k i p e d i a. O r g / W i k i / Asuransi_Kesehatan_Indonesia)

Andreas, 2009, Defisi Asuransi, Jakarta, Diakses tanggal 10 Desember 2011, (http://jurnal-sdm. blogspot.com/ 2009/08/ asuransi-insurance-assurance-definisi.html)

Ahuja R, 2004, Health Insurance for the Poor in India, Working Paper No. 123, Indian council for research on Interna- tional Economic Relations, New Delhi, India, D,iakses tanggal 22 Februari 2012, (http://www.icrier.org/ pdf/wp123.pdf).

Azwar, A, 1999, Pengantar Administrasi Kesehatan, Edisi Ketiga, Binarupa Aksara. Jakarta.

Bank Dunia, 2007, Peningkatan Keadaan Kesehatan Indonesia, Diakses tanggal 15 Desember 2011, (http:/ /peningkatan_keadaan_kesehatan_indonesia/ health2.pdf)

Biro Hukum \& Organisasi Departemen Kesehatan R.I, 2010, Jaminan Kesehatan Masyarakat Salah Satu Cara Mensejahterakan Rakyat, Jakarta Selatan, Diakses tanggal 15 Februari 2012 (http://www.jamkesmas_biro hukum.index.php.htm).

Departemen Kesehatan RI, 2009, Sistem Kesehatan Nasional, Jakarta.

Departemen Kesehatan RI, 2009, Rancangan Final: Rencana Pembangunan Jangka Panjang Bidang Kesehatan 20052025, Jakarta, Diakses tanggal 10 Desember 2011, (http: / / www.depkes.go.id/downloads / newdownloads/ rancangan_RPJPK_2005-2025.pdf).

Dural, 2008, Health Insurance Changes Highly Irresponsible, Herald letter with Media Watch, Diakses tanggal 11 Februari 2012, (http:/ /www.heraldletters.com.au/?=97)

Efendy F, 2010, Definisi Unsur dan Jenis Asuransi Kesehatan, Kumpulan Artikel Kesehatan Kedokteran, Keperawatan dan Kebidanan. FK Unhas, Makasar, (http://asuransi_kesehatan_definisi__unsur _dan_jenis_20101011839.htm)

Fernandez, B, 2005, Health Insurance: A Primer, CRS Report for Congress, The Library of Congress, Diakses tanggal 5 Maret2012, (http://www.law-umaryland-edu/ marshall/crsreports/crsdocuments/RL32237 02032005.pdf).

Gotama I, Pardede D. 2010. Reformasi Jaminan Sosial Kesehatan: Pembiayaan Kesehatan, Agenda dan IsuIsu Jaminan Kesehatan, Pusat Pembiayaan dan Jaminan Kesehatan Depkes R.I. Diakses tanggal 18 Januari 2012, (http://www.litbang.depkes.go.id/ download/ seminar/ desentralisasi6-80606/ makalah indra.pdf)

Henry, 2009, Reformasi Kesehatan, Washington, USA.

Insurance Provider, 2011, How do Poor People get Health Insurance, Diakses tanggal 10 Desember 2011, (http:/ /www.insuranceproviders.com/how-do-poor-peopleget-health-insurance).

International Labour Organization, 2008, Indonesia: Providing Health Insurance for The Poor, Subregional Office for South East Asia, Social Security Extension Initatives In South East Asia, Diakses tanggal 25 Januari 2012, (http://www.ilo.org/public/english/region/asro/ bangkok/ events/sis/ download/ paper25.pdf).

Jimmy, 2010, Asuransi Kesehatan. PT Askes, Wikipedia, Ensiklopedia bebas http://id.wikipedia.org/wiki/ Asuransi_kesehatan

Juanita, 2002, Peran Asuransi Kesehatan dalam Benchmarking Rumah Sakit dalam Menghadapi Krisis Ekonomi, Fakultas Kesehatan Masyarakat Jurusan Administrasi dan Kebijakan Kesehatan, Universitas Sumatera Utara, Diakses tanggal 12 Februari 2012, (www. repository.usu.ac.id/ bitstream/ 123456789/3747/1/ fkem-juanita5.pdf). 
Martin S.F, 2007, The Welfare Loss of Excess Health Insurance.

The Journal of Political Economy, Vol. 81, No. 2, Part 1.

(Mar. - Apr., 1973), pp. 251-280. Harvard University.

Diakses tanggal 20 Februari 2012, (http://

econ.duke.edu/ hf14/teaching/socialinsurance/ $\mathrm{r}$ eadings/ Feldstein73(3.11). pdf).

Medis Online, 2009, Medical Information and Services: Sistem Pembiayaan Kesehatan, Diakses tanggal 10 Januari 2012 (www. medisonline .net / article-journal / 41article/70-pembiayaan-kesehatan),

Mukti AG, A.G, 2010, Health Insurance. Wikipedia, Jakarta, Ensiklopedia bebas, Diakses tanggal 10 desember 2011, (http://www.asuransikesehatan.org).

Oecd, 2009, Health Insurance for The Rural Poor, Diakses tanggal 10 Desember 2011, (http://www.oecd.org/ dataoecd/31/38/2510517.pdf).

Richardson, C, 2009, Mandatory Health Insurance: Lesson from Massachusetts, USA, Diakses tanggal 23 Desember 2011, (http://www.cato.org/pubs/journal/cj29n2/cj29n27.pdf)

Thabrany, H, 2001, Asuransi Kesehatan di Indonesia. Pusat Kajian Ekonomi Kesehatan FKMUI, Depok, Indonesia. 